\title{
FAKTOR YANG MEMENGARUHI KREDIT BERMASALAH BANK KONVENSIONAL DAN SYARIAH DI INDONESIA
}

\section{FACTORS THAT INFLUENCE NON PERFORMING LOAN AND FINANCING IN INDONESIAN BANKING}

\author{
Risna Eka Pertiwi*), Yusman Syaukat ${ }^{* *}$, dan Dwi Rachmina $\left.{ }^{* * *}\right)$ \\ ${ }^{*}$ PT Bank Mega Syariah \\ Jl. HR Rasuna Said Kav 19A, Jakarta Selatan 12950 \\ ${ }^{* *}$ Departemen Ekonomi Sumberdaya dan Lingkungan, Fakultas Ekonomi dan Manajemen, IPB University \\ Jl. Agatis, Kampus IPB Darmaga, Bogor 16680 \\ ${ }^{* * *)}$ Departemen Agribisnis, Fakultas Ekonomi dan Manajemen, IPB University \\ Jl. Agatis, Kampus IPB Darmaga, Bogor 16680
}

\begin{abstract}
Credit risk is the risk that occurs when the borrower cannot pay an installment in the bank, both principle and interest. A bank's credit risk can be reflected in the value of the non-performing loan (NPL) in a conventional bank and the non-performing financing (NPF) in an Islamic bank. The study purposes were to analyze the influence of macroeconomic factors and the bank's internal factors to NPL and NPF. The data collected were quarterly data from 2008 to 2017 from 9 conventional banks and 3 Islamic banks. This study employed a panel data method. The results showed interest rate, growth of GDP and LDR that had a probability value of $<0.05$ against NPL, where at NPF only interest rate, exchange rate, growth of GDP had a probability value $<0.05$. We concluded that interest rate, growth of GDP and LDR had a significant effect on NPL while interest rate, exchange rate and growth of GDP factors significantly influenced $N P F$.
\end{abstract}

Keywords: NPL, NPF, interest rate, growth of GDP, panel data

\begin{abstract}
Abstrak: Risiko Kredit adalah risiko yang terjadi saat nasabah gagal memenuhi kewajibannya kepada bank, baik pokok maupun bunga. Risiko kredit bank tergambarkan dalam non performing loan (NPL) pada bank konvensional dan non performing financing (NPF) pada bank syariah. Tujuan penelitian ini adalah menganalisis pengaruh faktor makroekonomi dan internal bank terhadap NPL dan NPF. Sampel penelitian ini adalah 9 bank konvensional dan 3 bank syariah, dimana data yang digunakan adalah data triwulan dari tahun 2008 hingga 2017. Penelitian ini dianalisis menggunakan metode data panel. Hasil dari penelitian ini adalah hanya variabel suku bunga, pertumbuhan GDP dan LDR yang memiliki nilai probality $<0,05$ terhadap NPL, dimana pada NPF hanya suku bunga, nilai tukar dan pertumbuhan GDP yang memiliki nilai probality $>0,05$. Dari hasil tersebut dapat disimpulkan bahwa suku bunga, pertumbuhan GDP dan LDR berpengaruh signifikan terhadap NPL, sedangkan faktor yang berpengaruh signifikan terhadap NPF adalah suku bunga, nilai tukar dan pertumbuhan GDP.
\end{abstract}

Kata kunci: NPL, NPF, suku bunga, pertumbuhan GDP, data panel

\footnotetext{
${ }^{1}$ Alamat Korespondensi:

Email: riznbum@gmail.com
} 


\section{PENDAHULUAN}

Bank adalah badan usaha yang menghimpun dana dari masyarakat dalam bentuk simpanan dan menyalurkannya kepada masyarakat dalam bentuk kredit dan/atau bentuk-bentuk lainnya dalam rangka meningkatkan taraf hidup rakyat banyak. Dari dua kegiatan di atas ini lah bank memperoleh keuntungan (profit). Seiring dengan perkembangan dunia perbankan khususnya di Indonesia, terdapat dua jenis perbankan, yaitu Bank Konvensional dan Bank Syariah. Secara fungsi dan kegiatan operasional, kedua jenis bank tersebut memiliki fungsi yang sama. Perbedaan utama kedua jenis bank tersebut terdapat pada peraturan dan kebijakan yang berlaku, dimana peraturan Bank Konvensional dibuat berdasarkan peraturan dari regulator sedangkan peraturan Bank Syariah dibuat berdasarkan ketentuan fatwa dan/atau ketentuan yang ditetapkan oleh Dewan Syariah Islam.

Sama halnya dengan perusahaan pada umumnya, fokus utama bank adalah menghasilkan profit untuk pertumbuhan bank itu sendiri. Bukan hal yang mudah untuk menghimpun profit yang besar, karena di setiap kegiatan yang dilakukan bank terdapat berbagai macam risiko yang harus dihadapi, salah satunya adalah risiko kredit atau dalam perbankan syariah disebut risiko pembiayaan. Menurut POJK No.18 mengenai Manajemen Risiko, risiko kredit adalah risiko kegagalan pihak lain dalam memenuhi kewajiban kepada bank, termasuk risiko kredit akibat kegagalan debitur, risiko konsentrasi kredit, counterparty credit risk, dan settlement risk. Ada tidaknya kondisi tersebut menggambarkan kualitas kredit dari suatu bank.

Pada perbankan, risiko kredit suatu bank dapat tercerminkan melalui NPL (Non performing Loan) pada bank konvensional dan NPF (Non performing Financing) pada bank syariah. NPL dan NPF atau yang dapat disebut kredit bermasalah merupakan salah satu indikator kesehatan perbankan. Mehmood et al. (2013) menyatakan bahwa setiap bank memiliki alat dan cara berbeda dalam mengelola risiko kredit Meskipun memiliki tujuan yang sama yaitu menurunkan NPL. NPL memiliki pengaruh terhadap kondisi keuangan bank, karena saat suatu bank mengalami peningkatan rasio NPL maka bank tersebut mengalami kegagalan atau penurunan keuntungan/pendapatan.
Kredit bermasalah dapat terjadi dikarenakan beberapa hal, baik dari sisi bank ataupun nasabah itu sendiri, mulai dari faktor internal dan eksternal. Menurut Tampubolon (2004) penyebab utama terjadinya risiko kredit berasal dari internal bank. Standar pemberian kredit yang lunak atau longgar, manajemen kredit yang lemah, hingga bank tidak mampu membaca perubahan kondisi ekonomi menjadi penyebab timbulnya kredit bermasalah. Lebih lanjut menurut Rustam (2013) gagal bayar dapat disebabkan oleh dua hal, yaitu nasabah mampu namun tidak mau membayar dan nasabah yang tidak mampu membayar karena faktor eksternal seperti perubahan kondisi ekonomi yang dapat memengaruhi kondisi keuangan nasabah. Perubahan kondisi ekonomi dapat dilihat dari pergerakan beberapa indikator makroekonomi, seperti suku bunga, nilai tukar dan pertumbuhan GDP.

Berdasarkan latar belakang tersebut, maka penelitian ini dilakukan pada bank konvensional dan bank syariah di Indonesia yang beroperasi selama kurun waktu penelitian, yaitu 2008 hingga 2017. Faktorfaktor yang diteliti pada penelitian ini adalah faktor eksternal dan faktor internal bank yang diduga memiliki pengaruh terhadap perubahan nilai kredit bermasalah (NPL dan NPF), dimana faktor eksternal bank yang dimaksud dalam penelitian ini adalah fokus pada faktor makroekonomi (suku bunga, nilai tukar dan pertumbuhan GDP) sedangkan faktor internal bank yang digunakan adalah LDR/FDR.

Suku bunga adalah beban biaya yang dinyatakan dengan persentase tertentu dalam rangka peminjaman uang untuk jangka waktu tertentu (Mankiw et al. 2012). Pergerakan suku bunga kredit sangat memengaruhi kemampuan bayar atau tingkat pengembalian kredit nasabah. Semakin tinggi suku bunga, maka akan semakin tinggi pula pengembalian kredit yang harus dibayarkan oleh nasabah. Kondisi tersebut akan mengakibatkan semakin sulitnya nasabah dalam melunasi kredit (Faiz, 2010).

Nilai tukar adalah harga salah satu mata uang terhadap mata uang lain. Setiap negara memiliki kebijakan yang berbeda dalam hal nilai tukar (Dornbusch et al. 2008). Gremi (2013) menyatakan bahwa peningkatan nilai tukar dapat berdampak pada semakin besarnya nominal pembayaran kredit, diman hal tersebut dapat terjadi pada nasabah yang memiliki kredit valuta asing. 
Gross Domestic Product (GDP) atau di Indonesia disebut juga Produksi Domestik Bruto (PDB) adalah nilai seluruh barang dan jasa yang diproduksi di suatu negara dalam suatu periode tertentu (Dornbusch et al. 2008). GDP merupakan salah satu pendekatan dalam memahami konsep pendapatan nasional, diman dengan membandingkan data pendapatan nasional dari tahun ke tahun (pertumbuhan GDP) dapat menggambarkan tingkat pertumbuhan ekonomi, perubahan struktur ekonomi dan peningkatan taraf kemakmuran masyarakat. Tercerminnya taraf kemakmuran atau pendapatan masyarakat dari pertumbuhan GDP maka pertumbuhan GDP dapat dihubungkan dengan tingkat kemampuan bayar nasabah. Khemraj dan Pasha (2009) menjelaskan bahwa meningkatnya pendapatan masyarakat dalam hal ini nasabah bank dapat meningkatkan kemampuan nasabah dalam membayar kredit. Dengan meningkatnya kemampuan bayar kredit nasabah, maka NPL bank pun membaik (menurun).

Berdasarkan Peraturan Bank Indonesia No.15/15/ PBI/2013, Loan to Deposit Ratio (LDR) adalah rasio kredit yang diberikan kepada pihak ketiga dalam Rupiah dan valuta asing, tidak termasuk kredit kepada bank lain, terhadap dana pihak ketiga yang mencakup giro, tabungan, dan deposito dalam Rupiah dan valuta asing, tidak termasuk dana antar bank. Pada bank syariah, rasio ini disebut FDR (Loan to Deposit Ratio). Jika dihubungkan dengan kredit bermasalah, LDR/ FDR memiliki hubungan positif. Semakin tingginya kredit yang disalurkan bank, semakin besar resiko yang akan diterima bank, karena bank semakin longgar atau menurunnya kualitas penilaian nasabah kredit. Hal ini yang menyebabkan meningkatnya kredit bermasalah saat meningkatnya penyaluran kredit (Ekanayake dan Azzeez, 2015).

Penelitian Abid et al. (2013) yang dilakukan pada 16 negara di Tunisia dengan menggunakan metode data panel menghasilkan bahwa pertumbuhan GDP, tingkat inflasi dan suku bunga berpengaruh terhadap NPL. Namun, ketiga faktor makroekonomi tersebut bukan merupakan satu-satunya faktor yang berpengaruh. Buruknya manajemen juga dapat menjadi salah satu faktor yang berpengaruh pada tingginya NPL. Hal serupa juga ditemukan pada penelitian Skarica (2013) yang dilakukan pada beberapa bank di negara Eropa Timur dan Tengah dengan menggunakan metode panel data, diketahui bahwa penyebab utama dari tingginya NPL adalah menurunnya perekonomian, dimana secara statistika menunjukkan GDP, pengangguran dan inflasi merupakan faktor yang berpengaruh secara signifikan. Selain itu, juga ditemukan bahwa pertumbuhan GDP riil adalah penggerak utama dari meningkatnya ratio NPL selama 5 tahun terakhir.

Havidz dan Setiawan (2015) dalam penelitian mengenai faktor penyebab NPF yang dilakukan pada 4 bank syariah di Indonesia yang dianalisis menggunakan Panel Least Square dengan fixed effect model ditemukan bahwa faktor yang berpengaruh signifikan pada NPF adalah operational efficiency ratio (OER) dan pertumbuhan GDP, sedangkan ROA, FDR, CAR dan inflasi juga merupakan faktor yang bepengaruh pada NPF namun tidak signifikan. Pada penelitian Faiz (2010) yang dilakukan pada seluruh bank konvensional dan syariah di Indonesia menunjukkan hasil bahwa faktor yang berpengaruh negatif dan signifikan terhadap NPF adalah besarnya jumlah pembiayaan dan tingkat GDP. Untuk tingkat NPL sangat tergantung pada tingkat inflasi (hubungan positif) dan besarnya LDR (hubungan negatif).

Menurut Laporan Perekonomian Indonesia Tahun 2015 yang diterbitkan oleh Bank Indonesia, dinamika ekonomi global yang ditandai dengan berlanjutnya pelemahan ekonomi dunia, memberikan tekanan terhadap pertumbuhan ekonomi domestik pada tahun 2015. Perlambatan ekonomi domestik di tengah ketidakpastian pasar keuangan global yang tinggi meningkatkan risiko perekonomian dan menurunkan keyakinan pelaku ekonomi. Risiko perekonomian yang sempat mengemuka adalah risiko nilai tukar yang diiringi dengan menurunnya keyakinan terhadap perkonomian.

Terjadinya perlambatan pertumbuhan ekonomi domestik juga berdampak pada kinerja industri perbankan yang mengalami perlambatan pada tahun 2015. Meskipun terjadi perlambatan namun industri perbankan masih mampu menjaga profitabilitas tetap positif. Hanya saja terjadi perlambatan pertumbuhan kredit yang semula $11.6 \%$ pada tahun 2014 menjadi hanya $10,4 \%$ pada tahun 2015 . Tidak hanya itu, di tahun 2015 terjadi kenaikan NPL dan NPF menjadi 2,5\% dan 4,34\% pada tahun 2015 dari semula $2,16 \%$ dan $4,33 \%$ pada tahun 2014. Pada Gambar 1 dapat juga dilihat bahwa nilai tukar rupiah terhadap dollar mengalami peningkatan yang signifikan. Pada tahun 2008 nilai tukar rupiah sebesar Rp10.950 terus meningkat hingga Rp13.795 pada tahun 2015. 


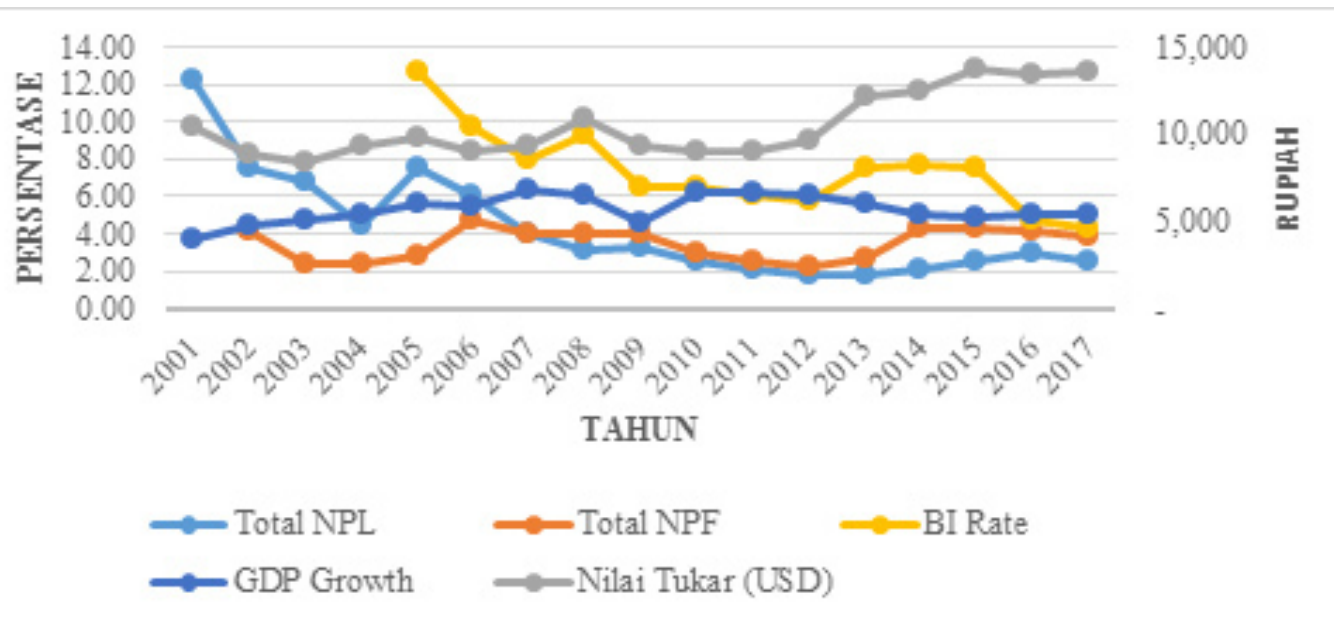

Gambar 1. Data NPL, NPF, suku bunga, pertumbuhan GDP dan nilai tukar Indonesia dari tahun $2001-2017$

Berdasarkan kondisi tersebut maka penelitian ini akan menganalisis pengaruh perubahan suku bunga (BI rate), nilai tukar rupiah terhadap dollar Amerika, pertumbuhan GDP dan LDR/FDR terhadap pergerakan NPL dan NPF di perbankan Indonesia. Hal ini perlu dilakukan agar para pihak yang terlibat dalam perekonomian Indonesia khususnya sektor perbankan dapat mengantisipasi kemungkinan terburuk yang akan terjadi apabila terjadi pergolakan dalam makroekonomi. Tujuan penelitian ini adalah menganalisis pengaruh suku bunga, nilai tukar, pertumbuhan GDP dan LDR terhadap perubahan nilai NPL pada bank konvensional di Indonesia. Selanjutnya, menganalisis pengaruh suku bunga, nilai tukar, pertumbuhan GDP dan FDR terhadap perubahan nilai NPF pada bank syariah di Indonesia.

\section{METODE PENELITIAN}

Penelitian ini dilakukan pada sembilan Bank Konvensional dan tiga Bank Syariah dengan kurun waktu penelitian adalah sepuluh tahun yaitu dari tahun 2008 hingga 2017 dengan menggunakan data triwulan. Bank konvensional yang terpilih merupakan bank konvensional yang masuk ke dalam 10 besar portofolio kredit Indonesia (telah mewakili 60\% kredit Indonesia) dalam kurun waktu 2008 hingga 2017. Terdapat satu bank yang tidak diikutsertakan karena mengalami merger pada akhir 2008. Bank syariah yang terpilih merupakan seluruh bank syariah yang eksis berdiri dari tahun 2008 hingga 2017 tanpa ada perubahan manajemen seperti merger atau akuisisi.
Data yang digunakan pada penelitian ini adalah data sekunder, baik untuk variabel dependen maupun variabel independen. Variabel dependen terdiri dari NPL Bank Konvensional dan NPF Bank Syariah, sedangkan variabel independen terdiri dari suku bunga, nilai tukar, pertumbuhan GDP dan LDR/FDR. Data tersebut diperoleh melalui metode dokumentasi dari lembagalembaga terkait seperti Bank Indonesia, Otoritas Jasa Keuangan, Badan Pusat Statistik dan lembaga terkait lainnya.

Data yang terkumpul akan diolah dan dianalisis menggunakan metode Regresi Data Panel, dimana pada proses analisis dilakukan beberapa tahap analisis yang terdiri dari penetuan model estimasi, penentuan metode estimasi dan uji asumsi klasik. Metode Regresi Data Panel digunakan untuk menjawab tujuan pertama dan kedua yaitu mengetahui pengaruh faktor makroekonomi dan internal bank terhadap NPL dan NPF di perbankan Indonesia. Model yang digunakan pada penelitian ini adalah sebagai berikut:

$\mathrm{NPL}_{i \mathrm{t}}=\alpha+\beta_{1} \mathrm{SB}_{\mathrm{it}}+\beta_{2} \mathrm{NT}_{\mathrm{it}}+\beta_{3} \mathrm{GGDP}_{\mathrm{it}}+\beta_{4} \mathrm{LDR}_{\mathrm{it}}+\varepsilon_{\mathrm{it}}$ $\mathrm{NPF}_{\mathrm{it}}=\alpha+\beta_{1} \mathrm{SBit}+\beta_{2} \mathrm{NT}_{\mathrm{it}}+\beta_{3} \mathrm{GGDP}_{\mathrm{it}}+\beta_{4} \mathrm{FDR}_{\mathrm{it}}+\varepsilon_{\mathrm{it}}$

Keterangan: NPL (kredit bermasalah pada bank konvensional (\%)); NPF (kredit bermasalah pada bank syariah (\%)); $\alpha$ (konstanta); $\beta$ (koefisien regresi); SB (suku bunga (\%)); NT(nilai tukar (rupiah)); GGDP (pertumbuhan gross domestic product (\%)); LDR (loan to deposit ratio); FDR (financing to deposit ratio); i (menunjukkan data cross section penelitian); $\mathrm{t}$ (menunjukkan data time series penelitian); $\varepsilon$ (error term). 
Kerangka pemikiran penelitian ini disajikan pada Gambar 2 yang menjelaskan bahwa Indonesia merupakan negara yang menganut dual banking system, di mana terdapat dua jenis bank, yaitu bank konvensional dan bank syariah. Dalam menjalankan bisnisnya, kedua jenis bank ini pasti dihadapkan pada berbagai macam risiko, salah satunya risiko kredit yaitu kredit bermasalah. Pada bank konvensional, kredit bermasalah disebut dengan NPL dan pada bank syariah disebut dengan NPF. Terdapat berbagai macam faktor yang dapat memengaruhi timbulnya kredit bermasalah, baik faktor eksternal maupun faktor internal bank. Faktor eksternal bank adalah hal-hal yang terjadi di luar kendali bank, seperti faktor makroekonomi, sedangkan faktor internal bank adalah faktor yang dimiliki oleh bank dan dapat dikendalikan oleh bank itu sendiri. Faktor makroekonomi yang diteliti pada penelitian ini adalah suku bunga, nilai tukar dan pertumbuhan GDP, sedangkan faktor internal bank yang diteliti hanya rasio penyaluran kredit/pembiayaan dengan total pendanaan (LDR/FDR). Berdasarkan kerangka pemikiran dan studi literatur, hipotesis dari penelitian ini adalah sebagai berikut :

H1 : Terdapat hubungan positif antara suku bunga, nilai tukar, dan LDR dengan nilai NPL serta hubungan negatif antara pertumbuhan GDP dengan nilai NPL

H2 : Terdapat hubungan positif antara suku bunga, nilai tukar dan FDR dengan nilai NPF serta hubungan negatif antara pertumbuhan GDP dengan nilai NPF

\section{HASIL}

\section{Statistik Deskriptif}

Hasil statistik deskriptif dari data-data yang digunakan dalam penelitian ini disajikan pada Tabel 1. Seluruh variabel baik dependen maupun independen dilakukan statistik deskriptif. Statistik deskriptif yang dilakukan meliputi jumlah data (observasi), nilai rata-rata (mean), nilai maksimum, nilai minimum dan standar deviasi.

Berdasarkan Tabel 1, jumlah data yang digunakan pada model NPL dari tahun 2008 hingga 2017 adalah sebanyak 360 data dan 120 data pada model NPF. Data NPL memiliki nilai rata-rata $2,88 \%$, dimana nilai NPL terbesar dimiliki oleh Bank Permata pada triwulan ke-4 tahun 2016, yaitu sebesar 8,83\%. Sedangkan nilai NPL terendah dimiliki oleh Bank Central Asia (BCA) yaitu sebesar $0,38 \%$ yang terjadi pada triwulan ke-4 tahun 2012. Pada model bank syariah rata-rata nilai variabel NPF selama 10 tahun waktu penelitian adalah 3,97\%, dimana nilai tertinggi yaitu $8,86 \%$ terjadi pada Bank Muamalat di triwulan ke-3 tahun 2009, sedangkan nilai terendah dimiliki oleh Bank Mega Syariah pada triwulan ke-1 tahun 2008 dengan nilai 1,06\%.

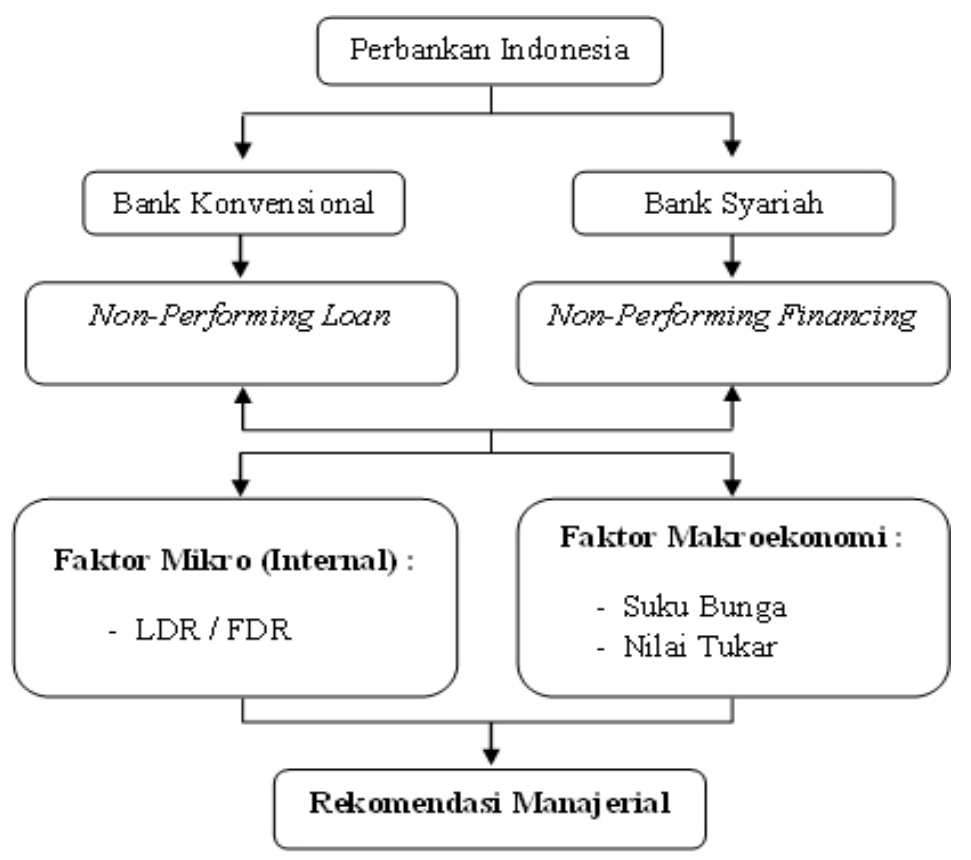

Gambar 2. Kerangka pemikiran penelitian 


\section{Pemilihan Model}

Pada penelitian ini terdapat dua model yang diuji menggunakan regresi data panel yaitu model NPL dan NPF. Pada regresi data panel, terdapat tiga pilihan model yang dapat digunakan, yaitu Pooled Least Square (PLS), Fixed Effect Model (FEM) dan Random Effect Model (REM). Hasil pemilihan model regresi disajikan pada Tabel 2, dimana disimpulkan bahwa baik model NPL maupun model NPF dalam melakukan analisis menggunakan regresi data panel, model terpilih yang akan digunakan adalah model FEM.

\section{Hasil Pengujian Asumsi Klasik}

Pada proses analisis data dengan menggunakan regresi data panel, tahapan lanjutan setelah menentukan model regresi yang tepat digunakan adalah tahap pengujian asumsi klasik. Pengujian ini dilakukan untuk melihat permasalahan yang dapat mengganggu hasil pengolahan dan kesimpulan atau persamaan model yang terbentuk. Hasil pengujian asumsi klasik disajikan pada Tabel 3, dimana baik model NPL maupun model NPF menunjukkan bahwa data yang digunakan pada penelitian ini telah memenuhi persyaratan statistik.

\section{Faktor-faktor yang Memengaruhi Kredit Bermasalah Bank Konvensional dan Syariah}

Berdasarkan uji yang telah dilakukan sebelumnya, baik model bank konvensional (NPL) maupun bank syariah (NPF), keduanya menggunakan model FEM dalam analisis regresi data panel. Dari uji regresi data panel tersebut dihasilkan variabel independen mana yang memiliki hubungan signifikan terhadap NPL atau NPF. Hasil uji regresi data panel untuk kedua model yang disajikan pada Tabel 4.

Tabel 1 Statistik deskriptif model kredit bermasalah pada bank konvensional dan bank syariah

\begin{tabular}{lccccc}
\hline & Jumlah observasi & Mean & Min & Maks & Std. Deviasi \\
\hline NPL & 360 & 2,88 & 0,38 & 8,83 & 1,33 \\
NPF & 120 & 3,97 & 1,06 & 8,86 & 1,60 \\
SB & 360 & 6,64 & 4,25 & 9,25 & 1,20 \\
NT & 360 & $11.044,80$ & $8.597,00$ & $14.657,00$ & $1.892,60$ \\
GGDP & 360 & 5,51 & 4,31 & 6,51 & 0,69 \\
LDR & 360 & 85,30 & 45,83 & 116,04 & 13,13 \\
FDR & 120 & 90,19 & 77,18 & 106,74 & 6,86 \\
\hline
\end{tabular}

Tabel 2 Hasil pemilihan model regresi data panel

\begin{tabular}{cccc}
\hline & Uji Chow & Uji Hausman & Model Terpilih \\
\hline NPL & $\mathrm{p}=0,0000$ & $\mathrm{p}=1,0000$ & FEM \\
& & (Cross-section test variance is invalid. Hausman statistic set to zero $)$ & \\
NPF & $\mathrm{p}=0,0000$ & - & FEM \\
\hline
\end{tabular}

Tabel 3 Hasil pengujian asumsi klasik

\begin{tabular}{lccc}
\hline & NPL & NPF & Hasil \\
\hline Uji Normalitas (Probability) & 0,000000 & 0,996647 & Sesuai \\
Uji Heteroskedasticitas (Prob. Chi-Square) & 0,6034 & 0,8826 & Sesuai \\
Uji Multikolinieritas & $<0,8$ & $<0,8$ & Sesuai \\
Uji Autokorelasi (Breusch-Godfrey Serial Correlation LM Test - Prob. Chi-Square) & 0,7525 & 1,0000 & Sesuai \\
\hline
\end{tabular}


Tabel 4. Hasil regresi data panel

\begin{tabular}{lcccc}
\hline & \multicolumn{2}{c}{ NPL } & \multicolumn{2}{c}{ NPF } \\
\cline { 2 - 5 } & Coefficient & Probability & Coefficient & Probability \\
\hline C & 10,06142 & 0,0047 & $-16,56846$ & 0,0258 \\
SB & $-0,067661^{*}$ & 0,0010 & $0,373445^{*}$ & 0,0000 \\
NT & $-0,210063$ & 0,5470 & $2,513294^{*}$ & 0,0005 \\
GGDP & $-0,189857^{*}$ & 0,0227 & $-0,739991^{*}$ & 0,0001 \\
LDR / FDR & $-0,043721^{*}$ & 0,0000 & $-0,013582$ & 0,3767 \\
\hline Adjst R-squared & \multicolumn{2}{c}{0,926824} & \multicolumn{2}{c}{0,011714} \\
Prob (F-statistic) & 0,000000 & & \multicolumn{2}{c}{0,00000} \\
\hline
\end{tabular}

*) signifikan pada taraf 5\%

\section{Pengaruh suku bunga, nilai tukar, pertumbuhan GDP dan LDR terhadap NPL}

Hasil analisis dengan menggunakan regresi data panel, menunjukkan bahwa variabel suku bunga memiliki hubungan signifikan terhadap NPL, tetapi berdampak negatif. Meskipun berbeda dengan teori yang ada, hasil ini sesuai dengan penelitian Ahmad dan Bashir (2013) dan Setiyaningsih et al. (2012) bahwa disaat suku bunga meningkat, NPL menurun. Hubungan negatif antara suku bunga dan NPL pun ditemukan pada penelitian Faiz (2010), dimana saat Kebijakan Bank Indonesia menurunkan suku bunga acuan, tidak serta merta perbankan menurunkan suku bunga kredit. Tingginya bunga yang dibebankan pada nasabah menyebabkan NPL meningkat. Hasil serupa pun ditemukan pada beberapa penelitian seperti Djauhari (2017) dan Musthikaningtyas (2011).

Variabel nilai tukar pada model NPL tidak memiliki hubungan signifikan terhadap NPL namun berdampak negatif. Meskipun tidak sesuai dengan teori yang menyatakan bahwa variabel nilai tukar berhubungan signifikan postif. Hasil penelitian ini sejalan dengan penelitian Abadi et al. (2014) dan Djauhari (2017) bahwa melemahnya nilai tukar rupiah terhadap dollar akan menyebabkan sektor-sektor yang memiliki orientasi penjualan dalam bentuk valas (ekspor) mengalami keuntungan sehingga meningkatkan kemampuan bayar kredit terhadap bank.

Pada penelitian ini, variabel pertumbuhan GDP memiliki hubungan signifikan negative terhadap NPL. Hasil ini sejalan dengan penelitian Akinlo dan Emmanuel (2014), Zaib et al. (2014) dan Rajha (2016) bahwa pertumbuhan ekonomi atau peningkatan GDP berdampak negatif terhadap NPL. Hal ini terjadi karena di saat terjadi penurunan GDP, ditemukan adanya penurunan penjualan dan pendapatan masyarakat. Kondisi tersebut memengaruhi kemampuan masyarakat atau perusahaan dalam mengembalikan pinjaman ke bank. Menurunnya kemampuan membayar ini yang selanjutnya menyebabkan meningkatnya outstanding pembiayaan non lancar (NPL/NPF) pada bank .

Variabel LDR pada penelitian ini memiliki hubungan signifikan negatif terhadap NPL. Meskipun hasil yang didapatkan berbeda dengan teori yang menyebutkan LDR memiliki hubungan signifikan positif dengan NPL, namun hasil penelitian ini sejalan dengan penelitian Ekanayake dan Azzeez (2015). Pada penelitian yang dilakukan di Srilanka tersebut ditemukan bahwa pertumbukan kredit (yang tercermin dalam peningkatan LDR) memiliki hubungan negatif dengan NPL, sebab bank komersial yang lebih agresif dalam menyalurkan kredit cenderung mengalami penurunan NPL.

\section{Pengaruh suku bunga, nilai tukar, pertumbuhan GDP dan FDR terhadap NPF}

Berbeda dengan model NPL, hasil analisis hubungan variabel suku bunga terhadap NPF sesuai dengan teori, yaitu suku bunga memiliki hubungan yang signifikan terhadap NPF dan berpengaruh positif. Hasil ini sesuai dengan penelitian Nuryartono et al. (2016) bahwa peningkatan suku bunga berdampak pada meningkatnya pengembalian angsuran atas pembiayaan yang dimiliki nasabah di bank, yang selanjutnya berdampak pada peningkatan NPF bank disebabkan menurunnya kemampuan nasabah membayar angsuran. Hal serupa juga ditemukan pada penelitian Setiawan dan Putri (2013) bahwa suku bunga memiliki efek signifikan positif terhadap NPF. Pada penelitian Harahap (2016) dijelaskan bahwa saat suku bunga (BI rate) naik, suku bunga pinjaman bank konvensional akan mengalami kenaikan. Hal tersebut dapat menguntungkan bank 
syariah karena margin dan bagi hasil bank syariah akan semakin bersaing dengan bunga bank konvensional. Semakin kompetitifnya margin \& bagi hasil bank syariah dapat meningkatnya penyaluran pembiayaan bank syariah. Meningkatnya penyaluran pembiayaan bank syariah dapat meningkatkan risiko terjadinya kredit bermasalah. Hal tersebut sesuai dengan penelitian ini bahwa suku bunga (BI rate) memiliki pengaruh signifikan dan berpengaruh positif terhadap NPF.

Hasil penelitian model NPF untuk variabel nilai tukar sesuai dengan teori yaitu variabel nilai tukar memiliki hubungan signifikan positif. Hasil ini sesuai dengan penelitian Haifa dan Wibowo (2014), bahwa kurs rupiah terhadap dollar berkorelasi positif dan signifikan terhadap NPF dalam jangka panjang. Nilai tukar yang terdepresiasi dapat melemahkan neraca perusahaan sehingga menurunkan kemampuan perusahaan dalam membayar kewajiban ke bank. Selain itu, pengaruh peningkatan nilai tukar terhadap peningkatan NPF juga dapat terjadi pada debitur yang meminjam kredit dalam mata uang asing. Meningkatnya nilai tukar rupiah dapat meningkatkan kewajiban pembayaran kredit debitur ke bank.

Hubungan signifikan negatif antara pertumbuhan GDP dengan kredit bermasalah tidak hanya terjadi pada bank konvensional, tetapi juga pada bank syariah. Pada penelitian Akbar (2016) dihasilkan bahwa GDP berpengaruh negatif terhadap NPF. Saat terjadi penurunan GDP ditemukan adanya penurunan penjualan dan pendapatan masyarakat. Dengan kondisi tersebut dapat memengaruhi kemampuan nasabah dalam mengembalikan pinjamannya dan menyebabkan meningkatnya kredit bermasalah (NPF). Sejalan dengan penelitian Firmansyah (2014) yang dilakukan pada BPRS di Indonesia, dihasilkan bahwa GDP berpengaruh negatif terhadap kredit bermasalah (NPF), dimana saat perekonomian meningkat, kredit bermasalah (NPF) pada BPRS menurun.

Pada model NPF, variabel FDR memiliki hubungan tidak signifikan negatif dengan NPF. Hubungan tidak signifikan FDR dengan NPF pada penelitian ini sejalan dengan penelitian Popita (2013) dan Asnaini (2017) sedangkan hubungan negatif antara variabel FDR dan NPF sejalan dengan penelitian Akbar (2016). Hubungan negatif antara FDR dengan NPF dapat terjadi karena peningkatan pembiayaan yang disalurkan bank syariah, dimana tergambar pada meningkatnya
FDR dapat menurunkan NPF. Hal tersebut disebabkan total pembiayaan yang disalurkan merupakan faktor pembagi dalam menghitung NPF. Oleh karena itu, saat pembiayaan meningkat, dapat menurunkan NPL.

\section{Implikasi Manajerial}

Hasil penelitian menunjukkan beberapa faktor yang memengaruhi kredit bermasalah pada bank konvensional dan bank syariah, dapat disimpulkan implikasi manajerial dari tiga aspek, yaitu bagi debitur, bagi perbankan dan bagi regulator. Bagi debitur, memahami kondisi ekonomi juga dibutuhkan oleh seorang debitur terutama para pelaku bisnis. Melihat hasil penelitian ini, saat yang paling tepat bagi para pelaku bisnis untuk meminjam uang ke bank adalah pada saat kondisi ekonomi membaik (GDP meningkat). Saat kondisi ini terjadi, bank akan lebih aktif memasarkan kredit karena dengan meningkatnya portofolio kredit disaat kondisi ekonomi membaik, diharapkan kualitas kredit perbankan akan membaik (NPL menurun). Kondisi ini pun menguntungkan bagi debitur karena mendapatkan tambahan dana dari bank disaat kondisi ekonomi membaik, dapat menunjang kinerja usaha debitur

Bagi perbankan, membaiknya kondisi ekonomi (GDP meningkat) menjadi waktu yang tepat untuk meningkatkan portofolio kredit dan memperbaiki kualitas kredit. Saat GDP meningkat, dimana inflasi pun meningkat, maka akan terjadi peningkatan sales. Meningkatnya sales akan disertai dengan meningkatnya kemampuan debitur dalam memenuhi kewajiban ke bank. Tidak hanya itu, meningkatnya sales dapat mengakibatkan debitur membutuhkan dana lebih untuk mengimbangi peningkatan sales. Kondisi ini lah yang dapat dimanfaatkan oleh perbankan. Baik bank konvensional maupun bank syariah, manajemen risiko khususnya risiko kredit merupakan hal yang penting dalam menjalankan bisnis kredit bank. Penyaluran kredit yang agresif tanpa memperhatikan aspekaspek baik internal maupun eksternal dapat menjadi masalah dikemudian hari, seperti meningkatnya kredit bermasalah karena ketidakmampuan nasabah dalam membayar kewajiban kreditnya ke bank. Perbankan pun diharap dapat membaca situasi makroekonomi sehingga dapat ditetapkan kebijakan internal yang dapat mengantisipasi perubahan ekonomi yang dapat berdampak pada kualitas kredit. 
Bagi regulator, sebagai pihak yang merumuskan sebuah keputusan atau kebijakan, diharapkan kebijakan yang diambil terkait perubahan ekonomi dapat mendukung perekonomian konvensional ataupun syariah. Jika melihat hasil penelitian ini, bank konvensional dan syariah memiliki respon yang berbeda atau bertolak belakang terhadap perubahan suku bunga. Oleh karena itu, Bank Indonesia selaku regulator yang menetapkan suku bunga diharapkan lebih bijak dalam menetapkan suku bunga sehingga tidak adanya pihak yang lebih diuntungkan dari keputusan tersebut.

\section{KESIMPULAN DAN SARAN}

\section{Kesimpulan}

Pada bank konvensional dari empat variabel independen yang dianalisis tiga diantaranya menunjukkan hasil yang signifikan atau memiliki pengaruh terhadap NPL. Variabel suku bunga, pertumbuhan GDP dan LDR memiliki pengaruh signifikan terhadap NPL. Ketiga faktor tersebut sama-sama memiliki hubungan negatif terhadap NPL. Satu variabel lain, yaitu nilai tukar, tidak memiliki pengaruh terhadap NPL meskipun memiliki hubungan negatif

Sama halnya dengan bank konvensional, pada bank syariah terdapat tiga variabel independen yang memiliki pengaruh pada NPF. Ketiga variabel tersebut adalah suku bunga, nilai tukar, dan pertumbuhan GDP. Suku bunga dan nilai tukar memiliki hubungan positif terhadap NPF, sedangkan pertumbuhan GDP memiliki hubungan negatif terhadap NPF. Pada penelitian ini, variabel FDR tidak memiliki hubungan signifikan terhadap NPF.

\section{Saran}

Bagi perbankan, saat terjadi perubahan kondisi ekonomi seperti meningkatnya suku bunga dan nilai tukar, melakukan peningkatan penyaluran kredit dapat menjadi salah satu cara dalam memperbaiki atau menurunkan risiko kredit. Pada pelaksanaannya, penyaluran kredit harus tetap menerapkan manajemen risiko yang baik, khususnya risiko kredit, sehingga apabila terjadi perubahan ekonomi tidak berdampak signifikan pada kondisi bank. Bagi regulator, diharapkan lebih bijak dalam menetapkan suatu keputusan seperti suku bunga, sehingga tidak adanya pihak yang lebih diuntungkan dari keputusan tersebut.
Melihat hasil penelitian ini dimana adjst R-squared NPL sebesar $92,7 \%$ dan NPF sebesar $61,2 \%$ maka penelitian terkait faktor yang memengaruhi NPF yang masih butuh dikembangkan. Terdapat 38,8\% keragaman NPF yang belum dijelaskan pada penelitian ini. Oleh karena itu, untuk penelitian selanjutnya dapat menambahkan beberapa hal seperti penambahan faktor internal, baik dari sisi bank atau dari sisi nasabah, penambahan faktor eksternal seperti kondisi ekonomi atau kondisi politik serta pengklasifikasian objek penelitian seperti dibedakan berdasarkan, jenis kredit, sektor ekonomi debitur, dan sebagainya.

\section{DAFTAR PUSTAKA}

Abadi S, Achsani NA, Rachmina D. 2014. The dynamics of non-performing loan in Indonesian banking industry: a sensitivity analysis using VECM approach. International Journal of Education and Research 2(8): 123-140.

Abid L, Ouertani MN, Ghorbel SZ. 2013. Macroeconomic \& bank-specific determinants of household's non-performing loans in Tunisia: a dynamic panel data. Procedia Economics and Finance 13: 58-68. https://doi.org/10.1016/ S2212-5671(14)00430-4.

Ahmad F, Bashir T. 2013. Explanatory power of macroeconomic variable as determinants of non-performing loans: evidence form Pakistan. World Applied Science Journal 22(2): 243-225. https://doi.org/10.5296/ajfa.v5i2.4133.

Akbar DA. 2016. Inflasi, gross domestic product (GDP), capital adequacy ratio (CAR) dan finance to deposit ratio (FDR) terhadap non-performing financing (NPF) pada bank umum syariah di Indonesia. I-Economic 2(2): 19-37.

Akinlo O, Emmanuel M. 2014. Determinants of nonperforming loans in Nigeria. Accounting \& Taxation 6(2): 21-28.

Asnaini SW. 2017. Faktor-faktor yang memengaruhi non performing financing pada bank umum syariah di Indonesia tahun 2010-2013. Jurnal STIE Insan Pembangunan 11(1): 1-10.

Djauhari RRA. 2017. Pengaruh variabel makroekonomi domestik dan internasional terhadap NPL sektoral perbankan di Indonesia [tesis]. Bogor: Institut Pertanian Bogor.

Dornbusch R, Fischer S, Startz R. 2008. Makroekonomi. Ed ke-10. Mirazudin RI, penerjemah. Wibisono Y, editor. Jakarta: PT Media Global Edukasi. 
Terjemahan dari Macroeconomics 10`th Ed.

Ekanayake EMNN, Azeez AA. 2015. Determinants of non-performing loans in licensed commercial banks: evidence from Srilanka. Asian Economic and Financial Review 5(6): 868-882. https://doi.org/10.18488/journal. aefr/2015.5.6/102.6.868.882.

Faiz IA. 2010. Ketahanan kredit perbankan syariah terhadap krisis keuangan global. La_Riba Jurnal Ekonomi Islam 4(2): 217-237. https:// doi.org/10.20885/lariba.vol4.iss2.art5.

Firmansyah I. 2014. Determinant of non performing loan: the case of islamic bank in Indonesia. Buletin Ekonomi Moneter dan Perbankan 17(2): 233-235. https://doi.org/10.21098/bemp. v17i2.51.

Gremi E. 2013. Macroeconomic factors that affect the quality of lending in Albania. Research Journal of Finance and Accounting 4(9): 50-57.

Haifa dan Wibowo D. 2015. Pengaruh faktor internal bank dan makro ekonomi terhadap non performing financing perbankan syariah di Indonesia: periode 2010:01-2014:04. Jurnal Nisbah 1(2): 74-87. https://doi.org/10.30997/ jn.v1i2.253.

Harahap MA. 2016. Faktor-faktor yang memengaruhi non performing financing pada bank syariah [tesis]. Medan: Universitas Islam Negeri Sumatera Utara.

Havidz SAH, Setiawan C. 2015. Bank efficiency and non-performing financing (NPF) in The Indonesian Islamic Banks. Asian Journal of Economic Modelling 3(3): 61-79. https://doi. org/10.18488/journal.8/2015.3.3/8.3.61.79.

Khemraj T, Pasha S. 2009. The determinants of nonperforming loans: an economics case study of Guyana. Munich Personal RePEc Archive 53128(23): 1-25.

Mankiw NG, Quah E, Wilson P. 2012. Pengantar Ekonomi Makro: Edisi Asia. Biro Bahasa Alkemia, penerjemah. Halim DA, editor. Jakarta: Penerbit Salemba Empat. Terjemahan dari: Principles of Economics: An Asian Edition.

Mehmood B, Younas ZI, Ahmed N. 2013. Macroeconomic and bank specific covariates of non-performing loans (NPLs) in Pakistan commercial banks: panel data evidence. Journal of Emerging Economics and Islamic Research 1(3): 1-15.

Musthikaningtyas NR. 2011. Analisis faktor-faktor yang memengaruhi non performing loan (NPL) kredit pemilikan rumah (KPR) [tesis]. Bogor: Institut Pertanian Bogor.

Nuryartono N, Saptono IT, Was'an GH. 2016. Kaitan kondisi makroekonomi dengan non performing financing (NPF) berdasarkan sektor ekonomi pada perbankan syariah di Indonesia. Jurnal Keuangan dan Perbankan 20(1): 104-115. https://doi.org/10.26905/jkdp.v20i1.153.

Popita MSAP. 2013. Analisis penyebab terjadinya non performing financing pada bank umum syariah di Indonesia. Accounting Analysis Journal 2(4): 404-412.

Rajha KS. 2016. Determinants of non-performing loans: evidence from the Jordanian banking sector. Journal of Finance and Bank Management 4(1): 125-136. https://doi.org/10.15640/jfbm.v5n1a5.

Rustam BR. 2013. Manajemen Risiko Perbankan Syariah di Indonesia. Jakarta: Salemba Empat.

Setiawan C, Putri ME. 2013. Non-performing financing and bank efficiency of Islamic banks in Indonesia. Journal of Islamic Finance and Business Research 2(1): 58-76.

Setiyaningsih, Juanda B, Fariyanti A. 2012. Faktor-faktor yang memengaruhi ratio on performing loan (NPL). Jurnal Aplikasi Bisnis dan Manajemen 1(1): 23-33. https://doi. org/10.17358/JABM.1.1.23.

Skarica B. 2013. Determinants of non-performing loans in Central and Eastern Europian Countries. Financial Theory and Practice 38(1): 37-59. https://doi.org/10.3326/fintp.38.1.2.

Tampubolon R. 2004. Risk Management Qualitative Approach Applied to Commercial Banks. Toruan RL, editor. Jakarta: PT Elex Media Komputindo.

Zaib A, Farid F, Khan MK. 2014. Macroeconomic and bank specific determinants of non performing loans in the banking sector in Pakistan. International Journal of Information, Business and Management 6(2): 53-81. 